\title{
Zinc phosphate protects tomato plants against Pseudomonas syringae pv. tomato
}

\author{
Mara Quaglia ${ }^{1} \cdot$ Marika Bocchini $^{1} \cdot$ Benedetta Orfei ${ }^{1} \cdot$ Roberto D'Amato $^{1} \cdot$ Franco Famiani $^{1} \cdot$ Chiaraluce Moretti $^{1}$ (i) . \\ Roberto Buonaurio ${ }^{1}$
}

Received: 29 September 2020 / Accepted: 12 February 2021 / Published online: 16 March 2021

(c) The Author(s) 2021

\begin{abstract}
The purpose of this study was to determine whether zinc phosphate treatments of tomato plants (Solanum lycopersicum $\mathrm{L}$.) can attenuate bacterial speck disease severity through reduction of Pseudomonas syringae pv. tomato (Pst) growth in planta and induce morphological and biochemical plant defence responses. Tomato plants were treated with $10 \mathrm{ppm}(25.90 \mu \mathrm{M})$ zinc phosphate and then spray inoculated with strain DAPP-PG 215, race 0 of Pst. Disease symptoms were recorded as chlorosis and/or necrosis per leaf $(\%)$ and as numbers of necrotic spots. Soil treatments with zinc phosphate protected susceptible tomato plants against $P s t$, with reductions in both disease severity and pathogen growth in planta. The reduction of Pst growth in planta combined with significantly higher zinc levels in zinc-phosphate-treated plants indicated direct antimicrobial toxicity of this microelement, as also confirmed by in vitro assays. Morphological (i.e. callose apposition) and biochemical (i.e., expression of salicylic-acid-dependent pathogenesis-related protein PRIbl gene) defence responses were induced by the zinc phosphate treatment, as demonstrated by histochemical and qPCR analyses, respectively. In conclusion, soil treatments with zinc phosphate can protect tomato plants against $P s t$ attacks through direct antimicrobial activity and induction of morphological and biochemical plant defence responses.
\end{abstract}

Keywords Pseudomonas syringae pv. tomato $\cdot$ Bacterial speck disease $\cdot$ Callose deposition · Integrated pest management PIN2 $\cdot$ PRIb1 $\cdot$ Resistance induction

\section{Introduction}

Bacterial speck disease is caused by Pseudomonas syringae pv. tomato (Okabe) Young, Dye \& Wilkie (Pst) and it represents one of the most important foliar diseases of tomato, as it can cause severe losses under cool and rainy conditions (Yunis et al. 1980; Shanin 2001). It also remains difficult to control. Although tomato genotypes with high or intermediate resistance to Pst are available on the market, as the pathogen has been shown to overcome this resistance (Buonaurio et al. 1996; Kunkeaw et al. 2010; Lin and Martin

Mara Quaglia and Marika Bocchini contributed equally to this work

Chiaraluce Moretti

chiaraluce.moretti@unipg.it

1 Department of Agricultural, Food and Environmental Sciences, University of Perugia, Borgo XX Giugno 74, 06121 Perugia, Italy
2007; Thapa and Coacker 2016), there is the need for further methods of control.

The European Union (EU) pesticides database (http:// ec.europa.eu/food/plant/pesticides/eu-pesticides-database) includes methods permitted for the control of plant pathogenic bacteria in the EU. These include microorganisms such as Aureobasidium pullulans DSM 14940 and DSM 14941, Bacillus subtilis QST 713 and Streptomyces lydicus WYEC 108. The bactericidal substances included are aluminium sulphate, benzoic acid, copper compounds, sodium hypochlorite and vinegar. Finally, there are also plant activators included, such as acibenzolar-S-methyl (ASM; also known as benzothiadiazole) and cerevisane (an inert extract obtained from cell walls of Saccharomyces cerevisiae LAS 117; Romeo ${ }^{\circledR}$, Sumitomo Chemical Italy). However, from among these, only commercial formulations based on the active ingredients of B. subtilis QST 713, copper and ASM are registered to date for use on tomato for control of bacterial speck disease. 
As reported in Commission Implementing Regulation (EU) 2016/673, the use of B. subtilis and copper compounds is permitted in organic tomato farming in the EU. Both of these have roles in the prevention of infections.

Treatments with copper-based formulations immediately before or after Pst infection have been shown to significantly reduce bacterial speck disease severity, both as plant stage and under climatic conditions optimal for disease development (Yunis et al. 1980). However, the effectiveness of these treatments has been reduced due to the appearance of copper-resistant Pst strains (Bender and Cooksey 1986; Cha and Cooksey 1991). Moreover, due to eco-toxicological issues, a maximum limit of $4 \mathrm{~kg} \mathrm{ha}^{-1}$ year $^{-1}$ for copper application has been imposed in Europe (Commission Implementing Regulation (EU) 2018/1981). These ecotoxicological aspects, and in particular copper persistence, bioaccumulation and toxicity, mean that copper compounds are now on the list of substances that are 'candidates for substitution', according to Regulation (European Commission) 2009/1107.

Inorganic salts represent a promising tool for both integrated and organic management of plant diseases, with some of them already commonly used in the food industry (Deliopoulos et al. 2010; Kuepper et al. 2001). According to the US Environmental Protection Agency (EPA 2018), inorganic salts such as potassium salts (e.g., bicarbonate, dihydrogen phosphate, silicate) can be termed 'biochemical pesticides'; i.e. substances found in nature (i.e. in animals, microbes, minerals, plants) that are effective for plant disease protection. Inorganic salts such as sodium bicarbonate are permitted in organic farming in Europe (Commission Implementing Regulations (EU) 2016/673, 2018/1584). The effectiveness of treatments with inorganic salts for the control of phytopathogenic oomycetes and fungi is well documented, as summarised in the review of Deliopoulos et al. (2010), while only limited data available on the protective effects of inorganic salts against phytopathogenic bacteria (Norman et al. 2006; Lin et al. 2008; Wen et al. 2009; Yaganza et al. 2014).

In this study, we tested the effects of zinc phosphate salt on bacterial speck disease severity, Pst growth in planta and in vitro, and on its induction of morphological and biochemical defence responses in tomato plants (i.e. callose deposition, accumulation of defence gene transcripts).

\section{Materials and methods}

\section{Plant treatments, bacterial growth and plant inoculation}

Tomato plants (Solanum lycopersicum L.) cv. Rio Grande were grown in peat for 4 weeks (to second to third true leaf stage) in a growth chamber at $22{ }^{\circ} \mathrm{C}$ to $24{ }^{\circ} \mathrm{C}$, with $240 \mu \mathrm{E} \mathrm{m}^{-2} \mathrm{~s}^{-1}$ illumination, and a 12-h light period. The plants were then transplanted into pots $\left(324 \mathrm{~cm}^{3}\right.$, one plant per pot) that contained peat (Traysubstrat, KlasmannDeilmann $\mathrm{GmbH}$ ) without (negative control) or with addition of $0.01 \mathrm{~g} \mathrm{~kg}^{-1}(10 \mathrm{ppm}, 25.90 \mu \mathrm{M})$ zinc phosphate [ $\mathrm{Zn}_{3}\left(\mathrm{PO}_{4}\right)_{2} ;$ Sigma-Aldrich, MO, Saint Louis, USA]. As reported by Gurmani et al. (2012), in tomato plants cv. Rio Grande application of zinc phosphate to soil (in a range from 0 to $0.015 \mathrm{~g} \mathrm{Kg}^{-1}$ ) exerted its highest effect on plant growth and yield at the dose of $0.01 \mathrm{~g} \mathrm{Kg}^{-1}$, the same used in our treatments. Plants were then kept in a growth chamber under the above-indicated conditions.

Zinc phosphate was chosen here since both zinc and phosphorus-based salts are known to induce disease resistance in plants (Alexandersson 2016; Orober et al. 2002; Tuzun and Bent 2006). Due to the poor solubility of zinc phosphate, we chose to incorporate it in soil for prolonging its eventual induced resistance capability. This zinc phosphate dose (10 ppm) was the most effective for reduction of bacterial speck disease severity while remaining non-phytotoxic, as we determined in preliminary experiments (Quaglia et al. unpublished data). ASM was used as the positive control (Bion 50 WG-50\% wettable granule formulation, $50 \%$ active ingredient; Syngenta Crop Protection, Monthey SA, Switzerland). This was applied as a soil drench (i.e. $50 \mathrm{~mL}$ per pot) from a water solution at $2.1 \times 10^{-4} \mathrm{~mol} \mathrm{~L}^{-1}$. This dose is reported in the literature as non-phytotoxic to tomato seedlings and plants, and protective against root-knot nematodes (Molinari 2014) and Pst (Scarponi et al. 2001). Moreover, it is similar to the dose that activates defence responses in tomato plants (Soylu et al. 2003).

After transplanting, each plant was irrigated with $50 \mathrm{~mL}$ water every 2 days until the end of the trial, and kept in a climatic chamber under the conditions reported above. At 14 days post-treatment (dpt), the tomato plants were spray inoculated with Pst DAPP-PG 215 race 0 (from the collection of the Department of Agricultural, Food and Environmental Sciences, University of Perugia, Italy). The inoculum was prepared by growing $P s t$ on nutrient agar medium (NA, Thermo Scientific Fisher, Germany) at $27 \pm 2{ }^{\circ} \mathrm{C}$ for $48 \mathrm{~h}$. These were then suspended in sterile distilled water and

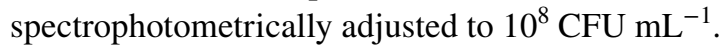

In the growth chamber, the plants were covered with plastic bags for the first $48 \mathrm{~h}$. Disease symptoms were recorded $15 \mathrm{dpi}$ in the youngest (third, fourth and fifth) inoculated leaves of each plant, by evaluation of the levels of chlorosis and/or necrosis per leaf area (\%), and counting of the number of necrotic spots on digital photos. For the purpose, the Assess software (Image Analysis Software for Plant Disease Quantification; APS Press, St. Paul, MN, USA; Lamari 2002) was used. Each experiment was 
independently repeated four times, with four replicates (plants) per treatment.

\section{Effects of zinc phosphate on Pseudomonas syringae pv. tomato growth in planta and in vitro}

The effects of the zinc phosphate and ASM (positive control) treatments on Pst growth in planta were determined at $6 \mathrm{dpi}$. This time-point was chosen as we previously reported that a decrease in Pst growth starting from 6 dpi in ASM-treated tomato plants (Scarponi et al. 2001). Three leaf disks (diameter, $10 \mathrm{~mm}$ ) from three leaflets of the third true leaf (where symptoms were more evident) were ground in a mortar with sterile deionised water. Leaf homogenates were diluted tenfold, and $100 \mu \mathrm{L}$ drops of each dilution were streaked onto NA plates. After $24 \mathrm{~h}$ incubation at $27 \pm 1^{\circ} \mathrm{C}$, the number of Pst colonies was counted. Each experiment was independently repeated twice, with four replicates (plants) per treatment.

The effects of zinc phosphate on in vitro Pst growth were determined using ELISA 96-well plates that contained $160 \mu \mathrm{L}$ King's B medium (King et al. 1954), $20 \mu \mathrm{L}$ bacterial suspension $\left(10^{8} \mathrm{CFU} \mathrm{mL} \mathrm{mL}^{-1}\right)$ and increasing concentrations of zinc phosphate $(0,25,40,50,60,75 \mathrm{ppm})$ in a final volume of $200 \mu \mathrm{L}$. To obtain the zinc phosphate concentration series, a $100 \mathrm{ppm}$ stock solution of zinc phosphate in $2 \%$ $\mathrm{HCl}$ was diluted as necessary. The effects of the increasing final $\mathrm{HCl}$ concentrations $(0.5 \%, 0.8 \%, 1.0 \%, 1.2 \%, 1.5 \%)$ on $P$ st growth were also determined. The plates were incubated at $27{ }^{\circ} \mathrm{C}$ in a microplate reader (Thermo Scientific MultiSkan EX; Thermo Fisher Scientific, Waltham, MA, USA) set for $5 \mathrm{~s}$ of shaking every minute, with the reading of the $\mathrm{OD}_{630}$ every hour for $24 \mathrm{~h}$. The data obtained from the $\mathrm{HCl}$ effects were subtracted from those obtained from the zinc phosphate samples. The effective concentrations (EC) were calculated in the exponential phase of the bacterial growth $(15 \mathrm{~h})$, as reported in the paragraph Statistical analysis.

\section{Determination of zinc and phosphorous levels in tomato leaves}

At 28 days post-treatment (dpt), three true leaves of the tomato plants (third, fourth, fifth) treated with water (negative control), zinc phosphate or ASM were oven-dried at $60{ }^{\circ} \mathrm{C}$ for $48 \mathrm{~h}$, and homogenised. The total zinc concentrations were determined following US-EPA Method 3052B (USEPA 1996). Briefly, $0.25 \mathrm{~g}$ of each sample was microwave-digested (Ethos One high-performance microwave digestion system; Milestone Inc., Sorisole, Bergamo, Italy) in the presence of ultrapure concentrated nitric acid $(65 \% \mathrm{w} / \mathrm{w})$ and $2 \mathrm{~mL}$ hydrogen peroxide $(30 \% \mathrm{w} / \mathrm{w})$, for $30 \mathrm{~min}$ at $1,000 \mathrm{~W}$ and $200{ }^{\circ} \mathrm{C}$. After cooling, the samples were diluted to $20 \mathrm{~mL}$ with Milli-Q water (18.2 M $\Omega$ ) and filtered (pore size, $0.22 \mu \mathrm{m}$ ). The zinc concentrations were determined using an atomic absorption spectrophotometer (AA-6200; Shimadzu, Tokyo, Japan). A range of zinc concentrations $\left(0.1-0.5 \mathrm{mg} \mathrm{L}^{-1}\right)$ was used as standards, and the zinc concentrations were determined for each sample by comparison with the standard curve. This method was accurately validated using a recovery test $(n=3)$ by adding a zinc standard solution $\left(4 \mathrm{mg} \mathrm{L}^{-1}\right)$ into a mixture of a zincenriched sample and nitric acid prior to digestion in tubes and after appropriate dilution, according to US-EPA Method 3052B. Once diluted, the same nitric acid solutions reported above were analysed spectrophotometrically for phosphorus content using a molybdic reagent, according to the method of Murphy and Riley (1962). Each experiment was independently repeated three times with three replicates (bulks of 10 plants each) per treatments.

\section{Callose quantification in tomato leaves}

At $48 \mathrm{~h}$ post-treatments (hpt) with water, zinc phosphate or ASM, small pieces of the leaves $(5 \times 5 \mathrm{~mm})$ were collected from the first leaflet of the third true leaf of the tomato plants and cleared in $96 \%$ ethanol at $80{ }^{\circ} \mathrm{C}$ for $10 \mathrm{~min}$. These were then stained with aniline blue (Carlo Erba Reagents S.r.l., Italy), as reported by Luna et al. (2011).

Callose quantification of the stained samples was performed by epifluorescence microscopy, equipped with UV filters (excitation, BP 365-395; barrier, LP 420) and using the ImageJ software (Quaglia et al. 2017). Each experiment was independently repeated three times with three plants and three leaf pieces per treatment, and a photograph was taken at random for each piece, for a total of nine replicates per treatment.

\section{RNA extraction and qRT-PCR analysis}

The fifth leaf of the tomato plants treated with water (negative control), zinc phosphate or ASM was collected at 24, 48 and $96 \mathrm{hpt}$ and snap-frozen in liquid nitrogen. Total RNA was extracted using PureLink RNA mini kits (Ambion, Life Technologies, Carlsbad, CA, USA), and DNase treatments were performed using the PureLink DNase set (Ambion, Life Technologies, Carlsbad, CA, USA). RNA concentrations were measured using a fluorimeter (Qubit 2.0; Thermo Fisher Scientific, BioRad, Hercules, CA) and assay kits (Qubit RNA BR). Five-hundred ng of total RNA was reverse transcribed into the first strand cDNA using the iScript cDNA synthesis kits (Bio-Rad Laboratories Inc., Hercules, CA, USA). Then, $5 \mu \mathrm{L}$ (20 ng) 1:20 cDNA (diluted in RNAse-free water) was mixed with $10 \mu \mathrm{L}$ SsoFast EvaGreen Supermix (Bio-Rad Laboratories Inc., Hercules, CA, USA); $0.4 \mu \mathrm{M}$ specific primers for the salicylic-acid-responsive tomato 'pathogenesis-related protein $1 \mathrm{~b} 1$ ' (PRIbl) gene 
(Goyal et al. 2016) and for the jasmonate-mediated 'proteinase inhibitor 2' (PIN2) gene (Castagna et al. 2007) (Supplementary Table S1) were added, in a $20 \mu \mathrm{L}$ reaction volume. The relative gene expression levels were normalised to actin (Goyal et al. 2016) and elongation factor 1- $\alpha(E F 1-\alpha)$ (Fowler et al. 2009), as the housekeeping genes (Supplementary Table 1). All of these reactions were carried out using a PCR machine (CFX96 Real-Time PCR Detection System; Bio-Rad, Hercules, CA, USA), where the PCR programme comprised: $98{ }^{\circ} \mathrm{C}$ for $2 \mathrm{~min}, 40$ cycles at $98^{\circ} \mathrm{C}$ for $3 \mathrm{~s}$ and $56{ }^{\circ} \mathrm{C}$ for $30 \mathrm{~s}, 95^{\circ} \mathrm{C}$ for $10 \mathrm{~s}$, cooling at $65^{\circ} \mathrm{C}$ for $1 \mathrm{~min}$, and finally an increase to $95{ }^{\circ} \mathrm{C}$ at a $0.2{ }^{\circ} \mathrm{C}$ increase every $10 \mathrm{~s}$, with measurement of fluorescence. A dissociation curve was included at the end of the $\mathrm{qPCR}$ programme to monitor for potential primer-dimers and non-specific amplification products. Threshold cycles $(\mathrm{Cq})$ were used to quantify the relative gene expression according to the method of Pfaffl (2001), and as modified in Vandesompele et al. (2002), to account for the two reference genes. Cq differences were calculated by adopting the $\mathrm{Cq}$ values for water application at $24 \mathrm{~h}$ as the treatment control. Normalised expression was $\log +1$ transformed before plotting and analysis. Each experiment was repeated independently twice, with three biological and technical replicates.

\section{Statistical analysis}

The data relating to the effects of the treatments on bacterial speck disease severity, in planta Pst growth, callose deposition, PRIb1 and PIN2 gene expression, and zinc and phosphorous levels were separately submitted to one-way (treatment) analysis of variance (ANOVA), with significant differences compared using Duncan multiple range tests, using the Excel software macro DSAASTAT (Onofri and Pannacci 2014). Details of the experimental settings are described in the Figure legends. The data related to the Pst in vitro growth were analysed using a nonlinear regression dose-response model proposed by Streibig et al. (1993), according to Eq. (1):

$Y=C+\frac{D-C}{1+\exp \{b[\log (X)-\log (a)]\}}$

where $Y$ is the bacterial growth reduction as a function of zinc phosphate concentration, $D$ is the upper asymptote (positive control response), $C$ is the lower asymptote (response of highest concentration tested), $a$ is the zinc phosphate concentration that gives the intermediate response between the upper and the lower asymptotes, and $b$ is the slope at the point of inflection.

The resulting dose-response curve was used to calculate the effective concentrations as $\mathrm{EC}_{10}, \mathrm{EC}_{50}$ and $\mathrm{EC}_{90}$, which indicate the concentrations of zinc phosphate corresponding to bacterial growth reductions of $10 \%, 50 \%$ and $90 \%$, respectively, with respect the untreated control (Pestemer and Günther 1995).

The data fitting to the nonlinear regression model was evaluated using lack-of-fit F-tests (Ritz and Streibig 2005). Statistical analysis was performed using the Excel software macros BIOASSAY97 and DSAASTAT (Onofri and Pannacci 2014).

\section{Results}

\section{Effect of zinc phosphate and ASM treatments on tomato plants protection from Pseudomonas syringae pv. tomato inoculation}

The leaves of the tomato plants grown in the soil with added $10 \mathrm{ppm}$ zinc phosphate were systemically protected against $P s t$ attack. Indeed, the treatments with zinc phosphate significantly reduced the $P$ st disease severity at $14 \mathrm{dpi}$, as expressed by the diseased areas of the leaves (\%) and numbers of bacterial spots per leaf (Fig. 1a, b). The significant reduction in the mean diseased area for the zinc phosphate treatment $(0.69 \%)$ was not significantly different to that for the ASM treatment $(0.81 \%)$ (Fig. 1a). Instead, a significant reduction in the mean number of spots per leaf with $10 \mathrm{ppm}$ zinc phosphate (17.02 spots per leaf) was more marked for the $2.1 \times 10^{-4} \mathrm{~mol} \mathrm{~L}^{-1} \mathrm{ASM}$ treatment (3.22 spots per leaf) (Fig. 1b).

For these tomato plants that were treated with zinc phosphate, at 6 dpi the reduction in disease severity was accompanied by a significant $(7.5 \%)$ reduction, from the control, of the in planta growth of $P s t$, with the ASM treatment showing a similar but greater reduction (10.3\%) (Fig. 1c).

The in vitro effects of different zinc phosphate concentrations on Pst growth were expressed as $\mathrm{OD}_{630}$ relative to the control (\%), and these fitted well to the log-logistic curve given in Eq. (2) (Fig. 2):

$y=100 /\{1+\exp [7.58(\log (x)-\log (45.9))]\}$

On the basis of this curve, the calculated effective concentrations for the zinc phosphate treatments are $34.3 \pm 3.53 \mathrm{ppm}$ $\left(\mathrm{EC}_{10}\right), 45.9 \pm 1.95 \mathrm{ppm}\left(\mathrm{EC}_{50}\right)$ and $61.3 \pm 5.55 \mathrm{ppm}\left(\mathrm{EC}_{90}\right)$.

\section{Effect of zinc phosphate treatments on the induction of callose deposition and defence gene expression}

A marked and significant increase in callose deposition was observed at $48 \mathrm{hpt}$ for the leaves of the tomato plants treated with zinc phosphate (10 ppm; 7.8-fold control), and the effect was comparable to that of the ASM treatment $\left(2.1 \times 10^{-4} \mathrm{~mol} \mathrm{~L}^{-1} ; 7.0\right.$-fold control) (Fig. 3). 


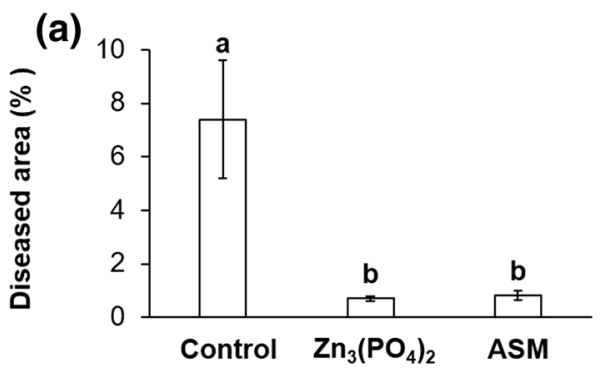

(b)

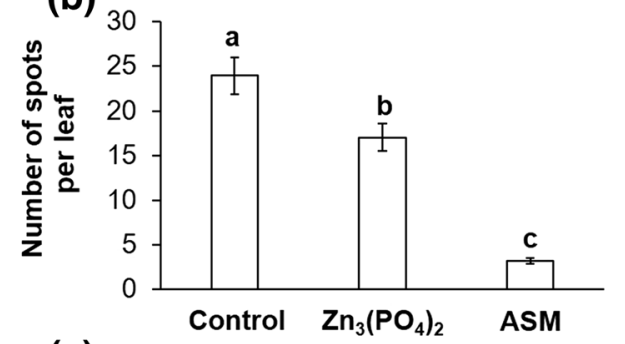

(c)

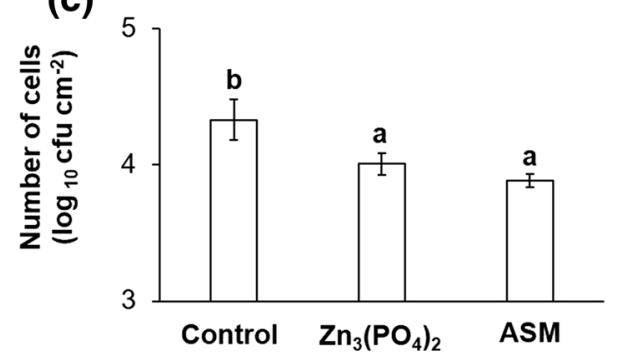

Fig. 1 Effects of zinc phosphate on bacterial speck disease severity and Pst growth in planta. Effects of the soil treatments of the tomato plants with water (control), zinc phosphate $\left[\mathrm{Zn}_{3}\left(\mathrm{PO}_{4}\right)_{2}\right.$; $10 \mathrm{ppm}(25.90 \mu \mathrm{M})]$ and acibenzolar-S-methyl (ASM; $2.1 \times 10^{-4} \mathrm{~mol}$ $\mathrm{L}^{-1}$ ) on bacterial speck disease severity expressed as diseased areas of the leaves $\mathbf{a}$ and numbers of spots per leaf $\mathbf{b}$ at $14 \mathrm{dpi}$, and on Pseudomonas syringae pv. tomato growth in planta at $6 \mathrm{dpi}$, as cell numbers per $\mathrm{cm}^{2}$ leaf c. Data are means \pm SE of 3 independent experiments and 4 replicates. Columns with different letters are significantly different $(p \leq 0.01, \mathbf{a}, \mathbf{b} ; p \leq 0.05$, c; Duncan's multiple range tests). CFU, colony forming units

Expression of the salicylic-acid-responsive $P R I$ gene was significantly induced for zinc phosphate- and ASMtreated tomato plants at 24, 48 and 96 hpt (Fig. 4a), which was maximal for $48 \mathrm{hpt}$ (3.5-fold, 6.5-fold, respectively). Also, a significant $50 \%$ reduction in the expression of the jasmonate-mediated PIN2 gene was observed for the zinc phosphate-treated plants at $24 \mathrm{hpt}$, but not for the ASM treatment (Fig. 4b).

\section{Effect of zinc phosphate treatments on zinc accumulation in the tomato leaves}

Significant zinc accumulation to 2.3-fold the control was detected in the leaves of the zinc phosphate-treated plants at $28 \mathrm{dpt}$ (Fig. 5a), while no differences were seen for the phosphorus levels (Fig. 5b).

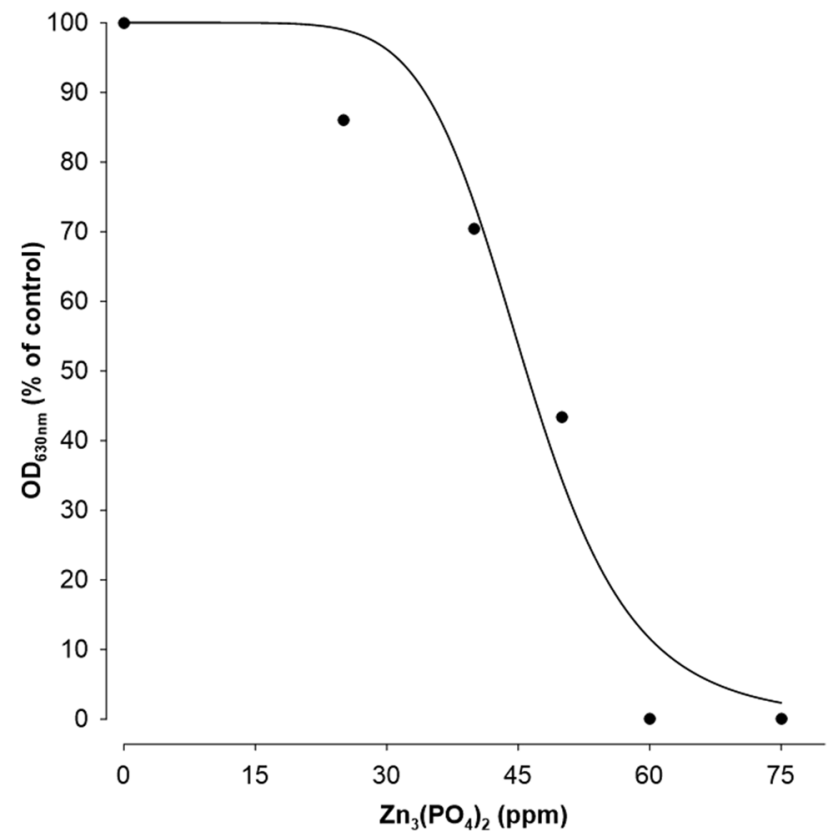

Fig. 2 Effects of zinc phosphate on in vitro Pst growth. Doseresponse curve for the growth of Pseudomonas syringae pv. tomato $\left(\mathrm{OD}_{630}\right.$, relative to control [\%]) versus concentration of zinc phosphate $\left(\mathrm{Zn}_{3}\left(\mathrm{PO}_{4}\right)_{2}\right)$ added. Closed circles represent the observed data $(n=8)$, and line is the log-logistic fitted curve $\mathrm{y}=100 /\{1+\exp [7.58$ $(\log (\mathrm{x})-\log (45.9))]\}$. The standard error of the mean is 0.0109

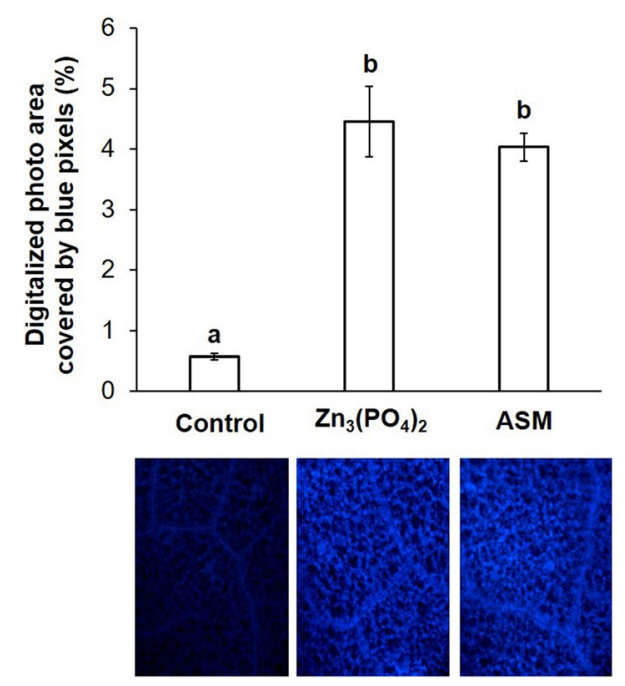

Fig. 3 Effects of zinc phosphate on callose deposition. Top: Callose deposition, expressed as percentage of digitalised photos covered by blue pixels, in leaves of tomato plants treated with water (control), zinc phosphate $\left[\mathrm{Zn}_{3}\left(\mathrm{PO}_{4}\right)_{2} ; 10 \mathrm{ppm}(25.90 \mu \mathrm{M})\right]$ or acibenzolar-Smethyl (ASM; $2.1 \times 10^{-4} \mathrm{~mol} \mathrm{~L}^{-1}$ ) at $48 \mathrm{hpt}$. Each column represents the mean of 27 replicated photos per treatment \pm SE. Columns with different letters are significantly different ( $p \leq 0.01$; Duncan's multiple range tests). Bottom: Representative images for callose deposition $(10 \times$ magnification $)$, as shown by blue pixels 

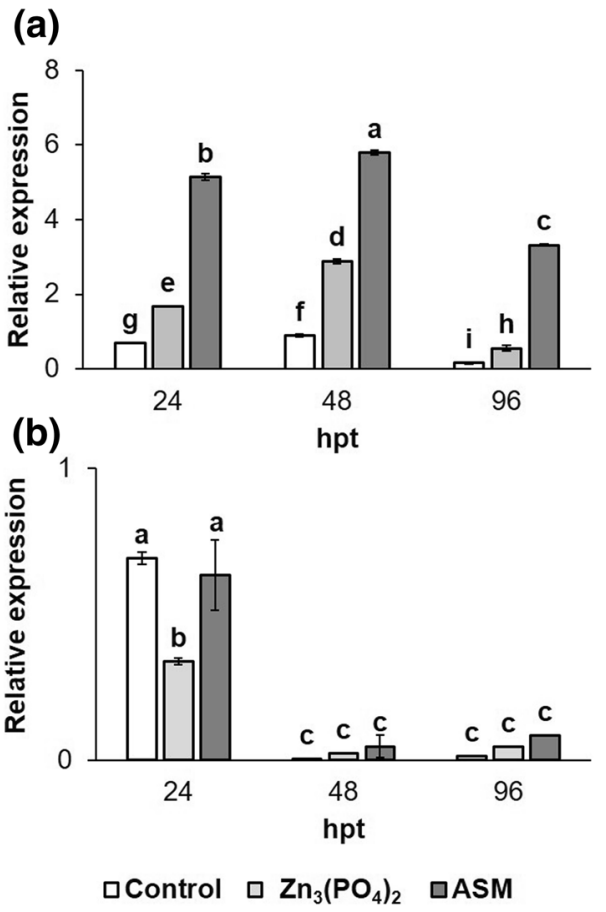

Fig. 4 Effects of zinc phosphate on defence gene induction. Relative expression levels of pathogenesis-related protein $(P R 1 b 1)$ a and tomato proteinase inhibitor 2 (PIN2) b genes in tomato (cv. Rio Grande) leaves at 24, 48 and $96 \mathrm{hpt}$ with water (control), zinc phosphate $\left[\mathrm{Zn}_{3}\left(\mathrm{PO}_{4}\right)_{2} ; 10 \mathrm{ppm}(25.90 \mu \mathrm{M})\right]$ or acibenzolar-S-methyl (ASM; $2.1 \times 10^{-4} \mathrm{~mol} \mathrm{~L}^{-1}$ ). Data are means of 9 replicates (3 biological, 3 technical $) \pm$ SE. Columns with different letters are significantly different ( $p \leq 0.01$; Duncan's multiple range tests)

\section{Discussion}

Zinc is one of the first elements that was discovered, and it is one of the main components of the Earth's crust (Duffy 2007). Zinc has a pivotal role in all living organisms, including animals, plants and microorganisms (Cabot et al. 2019). In plants, zinc is the sole metal that is associated with all the six enzyme classes (Coleman 1998), and it also has structural functions in proteins (Cabot et al. 2019). Zinc is involved in plant cell multiplication, water and nutrient uptake, phytohormone activities and plant responses to biotic and abiotic stresses (Cabot et al. 2019; Duffy 2007).

However, the role of zinc, applied to the soil (Grewal et al. 1996; Machado et al. 2018) or to the diseased peach shoots (Li et al. 2016), in plant defence responses is not unique, and instead varies in relation to the host-stress-factor combination (Cabot et al. 2019; Duffy 2007). Thus, in potato plants, zinc has been reported to reduce incidence and severity of powdery scab caused by Spongospora subterranea subsp. subterranea J.A. Toml., but it is ineffective against common scab caused by Streptomyces scabiei (Thaxt.) Lambert and Loria (Basu Chaudhary 1967; Falloon et al. 1995). Furthermore, zinc reduces the incidence and severity of crown
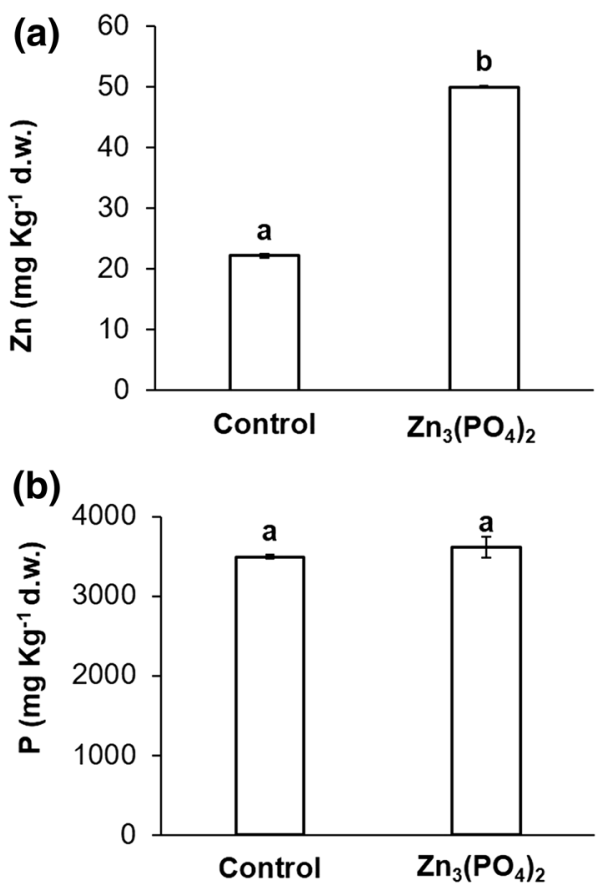

Fig. 5 Effects of zinc phosphate treatment on zinc and phosphorous levels in tomato leaves. Zinc a and phosphorus b contents $\left(\mathrm{mg} \mathrm{kg}^{-1}\right.$ dry weigh) in tomato (cv. Rio Grande) leaves $28 \mathrm{dpt}$ with water (control), zinc phosphate $\left[\mathrm{Zn}_{3}\left(\mathrm{PO}_{4}\right)_{2} ; 10 \mathrm{ppm}(25.90 \mu \mathrm{M})\right]$ or acibenzolar-S-methyl (ASM; $\left.2.1 \times 10^{-4} \mathrm{~mol} \mathrm{~L}^{-1}\right)$. Data are means of 3 independent experiments \pm SE. Columns with different letters are significantly different ( $p \leq 0.01$; Duncan's multiple range test). d.w., dry weight

and root rot caused by Fusarium graminearum Schwabe on wheat (Sparrow and Graham 1988), while it does not have the same efficacy towards Fusarium oxysporum f. sp. radicis-lycopersici on tomato (Duffy and Défago 1999).

Here, we have demonstrated that tomato plants grown in soil supplied with zinc phosphate are protected against $P s t$ attack, and that this protection was observed as reduced diseased areas and numbers of spots per leaf. This protection is also comparable to that provided by the resistance inducer ASM, although this was observed only for diseased areas of the leaves. In contrast, when expressed as numbers of spots per leaf, the protective effect of zinc phosphate was less marked with respect to that of ASM. This would indicate therefore that in the zinc phosphate-treated plants the diameters of the spots were lower than those for the ASMtreated plants. Similar data were obtained by Elsharkawy et al. (2018) in the same pathosystem, who used zinc oxide nanoparticles as a spray treatment for the leaves.

Pst growth was also repressed in the zinc phosphatetreated plants here. Similar findings have been reported for $P s t$ in zinc-supplied plants (Elsharkawy et al. 2018; Fones and Preston 2013) and for other pathogenic or beneficial bacteria (Othman et al. 2017; Zhang et al. 2015). This 
reduction of $P$ st growth in planta, combined with the significantly higher levels of zinc in the zinc phosphate-treated plants in comparison with controls suggest direct antimicrobial activity of this microelement (Cabot et al. 2019) even if we cannot exclude that a systemic acquired tolerance could be activated as the decrease of Pst population does not fully justify the reduction of symptoms. Similar findings were reported by Block et al. (2005) in tomato-Pst pathosystem. Zinc toxicity towards $P s t$ was ascertained in vitro using several concentrations of zinc phosphate. Similar results were reported by Elsharkawy et al. (2018) using zinc oxide nanoparticles and the agar disk diffusion technique. In particular, the $\mathrm{EC}_{50}$ of $46 \mathrm{ppm}$ zinc phosphate determined here in vitro was similar to the zinc concentration reached in the treated tomato plants $(50 \mathrm{ppm})$, which was more than twice that of the control plants. The zinc levels detected in our control plants (22.4 ppm) are supported by those reported for healthy crop species (Marschner 1995), including tomato (Karagiannidis et al. 2002; Ozores-Hampton et al. 1994). In preliminary experiments, we have observed no toxic effects of zinc at the concentrations applied and reached in our tomato plants. These results agree with those of Vijayarengan et al. (2013) and Cabot et al. (2019). In particular, Vijayarengan et al. (2013) reported that zinc exerted its toxic effect on tomato plants starting from a soil supply dose of $150 \mathrm{mg} \mathrm{Kg}^{-1}$, that is 15 times higher than those used in our treatments. Furthermore, in bioremediation experiments, the shoots chlorophyll content, an indicator of phytotoxicity, was not affected by zinc level higher than those reached in our tomato plants (Yamudna Devi et al. 2020). Of note, a zinc enrichment of plants could be useful in food and feed (Udechukwu et al. 2016) even if, high zinc doses (more than $50 \mathrm{mg}$ day $^{-1}$, World Health Organization https://apps.who. int/food-additives-contaminants-jecfa- database/chemical. aspx?chemID $=4197$ ) can cause adverse effects in humans and animals. This dose is compatible with that find in our tomato plants and in tomato fruits (Salam et al. 2011).

Phosphorus is the main nutrient that interacts with zinc in plants, including tomato plants. In particular, a negative relationship between these two nutrients has been documented during both their uptake and their transport and signalling (Bouain et al. 2014; Mousavi et al. 2012; Parker et al. 1992; Sainju et al. 2003; Soltangheisi et al. 2014). In agreement with that demonstrated by Mousavi (2011) and Mousavi et al. (2012), we observed that zinc applied to tomato plants reduces uptake and accumulation of phosphorus. Phosphate salts have been reported to induce resistance against pathogens in many plants, including solanaceous plants (Alexandersson 2016; Orober et al. 2002; Tuzun and Bent 2006). As the phosphorus levels in planta were not different between the control and zinc phosphate-treated tomato plants, we can speculate that the protective effects observed here were due to the zinc.
We have also demonstrated that zinc is involved in the induction of plant defence responses, in terms of callose apposition and $P R I b 1$ gene expression. In particular, the increased $P R 1 b 1$ gene expression observed in the zinc phosphate- and ASM-treated plants is in agreement with Elsharkawy et al. (2018) and Huang and Vallad (2018). For the PIN2 gene expression, in the three biological replicates we found that its expression was unchanged for both the zinc phosphate and ASM treatments, except for the reduction in the zinc phosphate-treated plants at the early treatment time $(24 \mathrm{hpt})$. These data are in agreement with Herman et al. (2007) for ASM treatment in tomato cv. Rio Grande.

It should be noted that callose apposition was induced in this zinc phosphate- and ASM-treated tomato plants. Although callose apposition after zinc phosphate or ASM treatments has been documented in several plant species (Benhamou and Bélanger 1998; Feigl et al. 2015; Kohler et al. 2002; Peterson and Rauser 1979), to the best of our knowledge, this is the first report of zinc phosphate induced callose apposition in tomato plants.

\section{Conclusions}

We have shown here that soil treatments with zinc phosphate inorganic salt protects tomato plants against $P s t$ attack, through the induction of morphological and biochemical plant defence responses and direct antimicrobial activity. In conclusion, zinc phosphate applied to the soil especially for greenhouse-cultivated tomatoes represents a valid means to support the plant defences against bacterial pathogens, particularly in organic farming, where ASM use is not permitted and the use of copper is being progressively restricted. Moreover, the use of molecules that can have both nutritional and protective roles matches the desire for reduced chemical input for crop production during eco-friendly agriculture.

Supplementary file 1 (DOCX 22 kb)Supplementary Information The online version contains supplementary material available at(https:// doi.org/10.1007/s41348-021-00444-z) .

Acknowledgments This study was supported through funding from POR-FESR 2014-2020 Asse 1-Ricerca e Innovazione: Valorizzazione degli scarti di biomasse destinate alla filiera agroalimentare. We also thank Dr. Christopher P. Berrie for advice on English use and Mr. Luca Bonciarelli and Dr. Maurizio Orfei for technical assistance.

Authors contributions Mara Quaglia, Chiaraluce Moretti and Roberto Buonaurio were involved in methodology, writing-review and editing, funding acquisition. Benedetta Orfei helped in methodology, data curation, writing first draft. Marika Bocchini contributed to methodology, data curation, software. Roberto D'Amato helped in data curation. Franco Famiani was involved in review and editing, funding acquisition. 
Funding Open access funding provided by Università degli Studi di Perugia within the CRUI-CARE Agreement.

\section{Declaration}

Conflict of interest The authors declare that they have no competing financial interests or personal relationships that could have influenced the work reported in this paper.

Open Access This article is licensed under a Creative Commons Attribution 4.0 International License, which permits use, sharing, adaptation, distribution and reproduction in any medium or format, as long as you give appropriate credit to the original author(s) and the source, provide a link to the Creative Commons licence, and indicate if changes were made. The images or other third party material in this article are included in the article's Creative Commons licence, unless indicated otherwise in a credit line to the material. If material is not included in the article's Creative Commons licence and your intended use is not permitted by statutory regulation or exceeds the permitted use, you will need to obtain permission directly from the copyright holder. To view a copy of this licence, visit http://creativecommons.org/licenses/by/4.0/.

\section{References}

Alexandersson E, Mulugeta T, Lankinen Å, Liljeroth E, Andersson E (2016) Plant resistance inducers against pathogens in Solanaceae species-from molecular mechanisms to field application. Int J Mol Sci. 17:1673. https://doi.org/10.3390/ijms17101673

Basu Chaudhary KC (1967) Influence of copper and zinc on the incidence of potato scab. Eur J Plant Pathol 73:49-51. https://doi.org/ 10.1007/BF01976522

Bender CL, Cooksey DA (1986) Indigenous plasmids in Pseudomonas syringae pv. tomato: conjugative transfer and role on copper resistance. J Bacteriol 165:534-541. https://doi.org/10.1128/jb. 165.2.534-541.1986

Benhamou N, Bélanger RR (1998) Benzothiadiazole-mediated induces resistance to Fusarium oxysporum f. sp. radicis-lycopersici in tomato. Plant Physiol 118:1023-1212. https://doi.org/10.1104/ pp.118.4.1203

Block A, Schmelz E, O’Donnell PJ, Jones JB, Klee HJ (2005) Systemic acquired tolerance to virulent bacterial pathogens in tomato. Plant Physiol 138:1481-1490

Bouain N, Shahzad Z, Rouached A, Khan GA, Berthomieu P, Abdelly C, Poirier Y, Rouached H (2014) Phosphate and zinc transport and signaling in plants: toward a better understanding of their homeostasis interaction. J Exp Bot 20:5725-5741. https://doi.org/ 10.1093/jxb/eru314

Buonaurio R, Stravato VM, Cappelli C (1996) Occurrence of Pseudomonas syringae pv. tomato race 1 in Italy on Pto gene-bearing tomato plants. J Phytopathol 144:437-440

Cabot C, Martos S, Llugany M, Gallego B, Tolrà R, Poschenrider C (2019) A role of zinc in plant defense against pathogens and herbivores. Front Plant Sci 10:1171. https://doi.org/10.3389/fpls. 2019.01171

Castagna A, Ederli L, Pasqualini S, Mensuali-Sodi A, Baldan B, Donnini S, Ranieri A (2007) The tomato ethylene receptor LEETR3(NR) is not involved in mediating ozone sensitivity: causal relationships among ethylene emission, oxidative burst and tissue damage. New Phytol 174:342-356. https://doi.org/10.1111/j. 1469-8137.2007.02010.x

Cha JS, Cooksey D (1991) Copper resistance in Pseudomonas syringae mediated by periplasmic and outer membrane proteins. PNAS USA 88:8915-8919. https://doi.org/10.1073/pnas.88.20.8915
Coleman JE (1998) Zinc enzymes. Curr Opin Chem Biol 2:222-234. https://doi.org/10.1016/s1367-5931(98)80064-1

Commission implementing regulation (EU) 2016/673 amending Regulation (EC) No 889/2008 laying down detailed rules for the implementation of Council Regulation (EC) No 834/2007 on organic production and labelling of organic products with regard to organic production, labelling and control. Official Journal of the European Union 116, 8-22. http://data.europa.eu/eli/reg_impl/ 2016/673/oj

Commission implementing regulation (EU) 2018/1584 amending Regulation (EC) No 889/2008 laying down detailed rules for the implementation of Council Regulation (EC) No 834/2007 on organic production and labelling of organic products with regard to organic production, labelling and control. Official Journal of the European Union 264, 1-12. http://data.europa.eu/eli/reg_impl/ 2018/1584/oj

Commission implementing regulation (EU) 2018/1981 renewing the approval of the active substances copper compounds, as candidate for substitution in accordance with Regulation (EC) $1107 / 2009$ of the European Parliament and of the Council concerning the placing of plant protection products on the market, and the Annex to Commission Implementing Regulation (EU) No 549/2011. Official Journal of the European Union 371, 16-20. http://data.europa.eu/eli/reg_impl/2018/1981/oj

Deliopoulos T, Kettlewell PS, Hare MC (2010) Fungal disease suppression by inorganic salts a review. Crop Prot 29:1059-1075

Duffy BK (2007) Zinc and plant diseases. In: Datnoff LDE, Elmer WH, Huber DM (eds) Mineral nutrition and plant disease. APS Press

Duffy BK, Défago G (1999) Macro- and microelement fertilizers influence the severity of Fusarium crown and root rot of tomato in soilless production system. Hort Sci 34:287-291. https://doi. org/10.21273/HORTSCI.34.2.287

Elsharkawy M, Derbalah A, Hamza A, El-Shaer A (2018) Zinc oxide nanostructure as a control strategy of bacterial speck of tomato caused by Pseudomonas syringae in Egypt. Environ Sci Poll. https://doi.org/10.1007/s11356-018-3806-0

EPA (Environmental Protection Agency) (2018) Biopesticide Registration. https://www.epa.gov/pesticide-registration/biopestici de-registration

Falloon RE, Viljanen-Rollinson SLH, Coles GD, Poff JD (1995) Disease severity keys for powdery and downy mildews of pea and powdery scab of potato. New Zeal J Crop H 23:31-37. https:// doi.org/10.1080/01140671.1995.9513865

Feigl G, Lehotai N, Molnár Á, Ördög A, Rodríguez-Ruiz M, Palma JM, Corpas FJ, Erdei L, Kolbert Z (2015) Zinc induces changes in the metabolism of reactive oxygen and nitrogen species (ROS and RNS) in the roots of two Brassica species with different sensitivity to zinc stress. Ann Bot 116:613-625. https://doi.org/ 10.1093/aob/mcu246

Fones HN, Preston GM (2013) The impact of transition metals on bacterial plant disease. FEMS Microbiol Rev 37:495-519. https://doi.org/10.1111/1574-6976.12004

Fowler JH, Narváez-Vásquez J, Aromdee DN, Pautot V, Holzer FM, Walling LL (2009) Leucine aminopeptidase regulates defense and wound signalling in tomato downstream of jasmonic acid. Plant Cell 21:1239-1251. https://doi.org/10.1105/tpc.108. 065029

Goyal RK, Fatima T, Topuz M, Bernadec A, Sicher R, Handa AK, Mattoo AK (2016) Pathogenesis-related protein 1b1 (PR1b1) is a major tomato fruit protein responsive to chilling temperature and upregulated in high polyamine transgenic genotyopes. Front Plant Sci 7:901. https://doi.org/10.3389/fpls.2016.00901

Grewal HS, Graham RD, Rengel Z (1996) Genotypic variation in zinc efficiency and resistance to crown rot disease (Fusarium 
graminearum Schw Group 1) in wheat. Plant Soil 186:219-226. https://doi.org/10.1007/BF02415517

Gurmani AR, Din JU, Khan SU, Andaleep R, Waseem K, Khan A (2012) Soil application of zinc improves growth and yield of tomato. Int J Agric Biol 14:91-96

Herman MAB, Restrepo S, Smart CD (2007) Defense gene expression patterns of three SAR induced tomato cultivars in the field. Physiol Mol Plant P. 71: 192-200.

Huang C, Vallad GE (2018) Soil applications of acibenzolar-S-methyl induce defense gene expression in tomato plants against bacterial spot. Eur J Plant Pathol 150:971-981. https://doi.org/10.1007/ s10658-017-1336-0

Karagiannidis N, Bletsos F, Stavropoulos N (2002) Effect of Verticillium wilt (Verticillium dahliae Kleb.) and mycorrhiza (Glomus mosseae) on root colonization, growth and nutrient uptake in tomato and eggplant seedlings. Sci Hort 94:145-156. https://doi. org/10.1016/S0304-4238(01)00336-3

King EO, Ward MK, Raney DE (1954) Two simple media for the demonstration of pyocyanin and fluorescin. Translational Res 44:301-307

Kohler A, Schwindling S, Conrath U (2002) Benzothiadiazoleinduced priming for potential responses to pathogen infection, wounding, and infiltration of water into leaves requires the NPR1/NIM1 gene in Arabidopsis. Plant Physiol 128:1046-1056. https://doi.org/10.1104/pp.010744

Kuepper G, Thomas R, Earles R (2001) Use of baking soda as a fungicide. National centre for appropriate technology, Faytteville, AR. http://attra.ncat.org/attrapub/bakingsoda.html

Kunkeaw S, Tan S, Coaker G (2010) Molecular and evolutionary analyses of Pseudomonas syringae pv. tomato race 1 . Mol Plant Microbe Interact 23:415-424. https://doi.org/10.1094/ MPMI-23-4-0415

Lamari L (2002) ASSESS: Image analysis software for plant disease quantification. APS Press, St. Paul, MN

Li Z, Fan YC, Gao L, Cao X, Ye JL, Li GH (2016) The dual roles of zinc sulfate in mitigating peach gummosis. Plant Dis 100:345351. https://doi.org/10.1094/PDIS-01-15-0131-RE

Lin CH, Hsu ST, Tzeng KC, Wang JF (2008) Application of a preliminary screen to select locally adapted resistant rootstock and soil amendment for integrated management of tomato bacterial wilt in Taiwan. Plant Dis 92:909-916. https://doi.org/10.1094/ PDIS-92-6-0909

Lin NC, Martin GB (2007) Pto- and Prf-mediated recognition of AvrPto and AvrPtoB restricts the ability of diverse Pseudomonas syringae pathovars to infect tomato. Mol Plant Microbe Interact 20:806-815. https://doi.org/10.1094/MPMI-20-7-0806

Luna E, Pastor V, Robert J, Flors V, Mauch-Mani B, Ton J (2011) Callose deposition: a multifaceted plant defense response. Mol Plant Microbe Interact 24:183-193. https://doi.org/10.1094/ MPMI-07-10-0149

Machado PP, Steiner F, Zuffo AM, Machado RA (2018) Could the supply of boron and zinc improve resistance of potato to early blight? Potato Res 61:169-182. https://doi.org/10.1007/ s11540-018-9365-4

Marscher H (1995) Mineral nutrition of higher plants, 2nd edn. Academic Press, London, UK

Murphy J, Riley JP (1962) A modified single-solution method for the determination of phosphorus in natural waters. Anal Chim Acta 27:31-36. https://doi.org/10.1016/S0003-2670(00)88444-5

Molinari S (2014) Systemic acquired resistance activation in solanaceous crops as a management strategy against root-knot nematodes. Pest Manag Sci 72:888-896. https://doi.org/10.1002/ps. 4063

Mousavi SR, Galavi M, Rezaei M (2012) The interaction of zinc with other elements in plants: a review. Int J Agri Crop Sci 4:1881-1884
Mousavi SR (2011) Zinc in crop production and interaction with phosphorus. AJBAS 5(9):1503-1509

Norman DJ, Chen J, Yuen JMF, Mangravita-Novo A, Byrne D, Walsh L (2006) Control of bacterial wilt of geranium with phosphorous acid. Plant Dis 90:798-802. https://doi.org/10. 1094/PD-90-0798

Onofri A, Pannacci E (2014) Spreadsheet tools for biometry classes in crop science programmes. Commun Biometry Crop Sci 9:3-13

Othman NMI, Othman R, Saud HM, Wahab PEM (2017) Effects of root colonization by zinc-solubilizing bacteria on rice plant (Oryza sativa MR2199) growth. Agric Nat Resour 51:532-537. https://doi.org/10.1016/j.anres.2018.05.004

Orober M, Siegrist J, Buchenauer H (2002) Mechanisms of phosphate-induced disease resistance in Cucumber. Eur J Plant Pathol 108:345-353. https://doi.org/10.1023/A:1015696408402

Ozores-Hampton M, Schaffer B, Bryan HH, Hanlon EA (1994) Nutrient concentrations growth and yield of tomato and squash in municipal solid waste amended soil. Hort Sci 29:785-788. https:// doi.org/10.21273/HORTSCI.29.7.785

Parker DR, Aguilera JJ, Thomason DN (1992) Zinc-phosphorus interaction in two cultivars of tomato (Lycopersicon esculentum L.) grown in chelator-buffered nutrient solutions. Plant Soil 143:163177. https://doi.org/10.1007/BF00007870

Pestemer W, Günther P (1995) Growth inhibition of plants as a bioassay for herbicide analysis. Chemical Plant Protection 11:219-231

Peterson CA, Rauser WE (1979) Callose deposition and photoassimilate export in Phaseolus vulgaris exposed to excess cobalt, nichel, and zinc. Plant Physiol 63:1170-1174. https://doi.org/10.1104/ pp.63.6.1170

Pfaffl MW (2001) A new mathematical model for relative quantification in real-time RT-PCR. Nucleic Acids Res 29:e45. https://doi.org/ 10.1093/nar/29.9.e45

Quaglia M, Baglivo F, Moretti C (2017) Postharvest $\beta$-aminobutyricacid-primed resistance is not effective in the control of Penicillium expansum Link. on 'Golden delicious' apple fruit. Crop Prot 102:43-48. https://doi.org/10.1016/j.cropro.2017.06.025

Regulation (EC) 2009/1107 of the European Parliament and of the Council of 21 October 2009 concerning the placing of plant protection products on the market and repealing Council Directives 79/117/EEC and 91/414/EEC. O J 309, 1-50. http://data.europa. eu/eli/reg/2009/1107/oj

Ritz C, Streibig JC (2005) Bioassay analysis using R. J Stat Softw $12: 1-22$

Sainju UM, Dris R, Singh B (2003) Mineral nutrition of tomato. Food Agri Environ 1:176-183

Salam MA, Siddique MA, Rahim MA, Rahman MA, Goffar MA (2011) Quality of tomato as influenced by boron and zinc in presence of different doses of cowdung. Bangladesh J Agril Res 36(1):151-163

Scarponi L, Buonaurio R, Martinetti L (2001) Persistence and translocation of a benzothiadiazole derivative in tomato plants in relation to systemic acquired resistance against Pseudomonas syringae pv. tomato. Pest Mang Sci 57:262-268. https://doi.org/10.1002/ ps. 285

Shanin F (2001) Severe outbreak of bacterial speck, caused by Pseudomonas syringae pv tomato on field-grown tomatoes in the eastern anatolia region of Turkey. Plant Pathol 50:799. https://doi.org/ 10.1046/j.1365-3059.2001.00622.x

Soltangheisi A, Rahman ZA, Ishak CF, Musa HM, Zakikhani H (2014) Interaction effects of phosphorus and zinc on their uptake and ${ }^{32} \mathrm{P}$ absorption and translocation in sweet corn (Zea mays var. saccaharata) grown in a tropical soil. Asian J Plant Sci 13:129-135. https://doi.org/10.3923/ajps.2014.129.135

Soylu S, Baysal O, Soylu EM (2003) Induction of disease resistance by the plant activator, acibenzolar- $S$-methyl (ASM), against bacterial canker (Clavibacter michiganensis subsp. michiganensis) in 
tomato seedlings. Plant Sci 165:1069-1075. https://doi.org/10. 1016/S0168-9452(03)00302-9

Sparrow DH, Graham RD (1988) Susceptibility of zinc-deficient wheat plants to colonization by Fusarium graminearum Schw. group 1. Plant Soil 112:261-266. https://doi.org/10.1007/BF02140004

Streibig JC, Rudemo M, Jensen JE (1993) Dose-response curves and statistical models. In: Streibig JC, Kudsk P Herbicide Bioassay. CRC Press, Boca Raton.

Thapa SP, Coacker G (2016) Genome sequences of two Pseudomonas syringae pv. tomato race 1 strains, isolated from tomato fields in California. Genome Announc 4:e01671-e1715. https://doi.org/10. 1128/genomeA.01671-15

Tuzun S, Bent E (2006) Multigenic and induced systemic resistance in plants. https://doi.org/10.1007/b101085

USEPA (United States Environmental Protection Agency) (1996) EPA Method 3052B, Microwave assisted acid digestion of siliceous and organically based matrices. In: Test methods for Evaluating Solid Waste, Physical/Chemical methods. Washington DC, Washington, USA

Udechukwu MC, Collins SA, Udenigwe CC (2016) Prospects of enhancing dietary zinc bioavailability with food-derived zincchelating peptides. Food Funct 7(10):4137-4144. https://doi.org/ 10.1039/c6fo00706f

Vandesompele J, De Preter K, Pattyn F, Poppe B, Van Roy N, De Paepe A, Speleman F (2002) Accurate normalization of real-time quantitative RT-PCR data by geometric averaging of multiple internal control genes. Genome Biol 3:research0034-1.

Vijayarengan P, Mahalakshmi G, Words K (2013) Zinc toxicity in tomato plants. World Appl Sci J 24:649-653. https://doi.org/10. 5829/idosi.wasj.2013.24.05.2249
Wen A, Balogh B, Momol MT, Olson SM, Jones JB (2009) Management of bacterial spot of tomato with phosphorous acid salts. Crop Prot 28:859-863. https://doi.org/10.1016/j.cropro.2009.04.013

Yaganza ES, Tweddell RJ, Arul J (2014) Postharvest application of organic and inorganic salts to control potato (Solanum tuberosum L.) storage soft rot: plant tissue-salt physicochemical interaction. J Agric Food Chem 62:9223-9231. https://doi.org/10.1021/jf501 7863

Yamudna Devi S, Surendran A, Thatheyus AJ (2020) Bioremoval of zinc using tomato plant Lycopersicon esculentum. JPHI 3(1):7-19. https://doi.org/10.14302/issn.2641-4538.jphi-20-3475

Yunis H, Bashan Y, Okon Y, Henis Y (1980) Weather dependence, yield losses, and control of bacterial speck of tomato caused by Pseudomonas tomato. Plant Dis 64:937-939. https://doi.org/10. 1094/PD-64-937

Zhang MQ, Guo Y, Powell CA, Doud MS, Yang CY, Zhou H, Duan YP (2015) Zinc treatment increases the title of 'Candidatus Liberibacter asiaticus' in huanglongbing-affected citrus plants while affecting the bacterial microbiomes. J Appl Microbiol 120:16161628. https://doi.org/10.1111/jam.13102

Publisher's Note Springer Nature remains neutral with regard to jurisdictional claims in published maps and institutional affiliations. 